\title{
The Fight for the Power and the Other One in Politics
}

\author{
Hasan Jashari \\ SEE University
}

\begin{abstract}
In politics we will always have friends, opponents and outsiders. They constantly appear to us and at that moment when we have won one and as such has lost the support of the electorate. But political struggle goes on with other people who use the loss of one to take his post in the electorate. But even the opposition has its announced and not announced opponents. The purpose of this research is that through the theoretical and empirical elaboration of the topic we will collect data on the political power struggle between the four main political parties in Macedonia. By means of statistical data, previous surveys and surveys of 100 students we will analyze various indicators and will make their interpretation. Today, in our political and social level, we all work against one another. To work against others, strategies must be prepared to carry out self-proclaiming to the people, how to deface the opponent, how to elaborate, reveal discoveries about the shortcomings and weaknesses of the enemy camp. It is summed up in the goals - to have information that the other is corrupt, unable,so that we can attack. But the question is that working against others is it becoming a political philosophy and permanent strategy,is it becoming a business, but also a struggle without any moral boundaries, especially in Macedonia but also in Albania and Kosovo.
\end{abstract}

Keywords: power, majority, minority, political parties, the other

\section{Introduction}

In the last decade, Macedonia has had different situations of power struggle. In the 2006 elections between the Albanian parties competing at that time for the Republican Parliament, were also used hand balls (the mines Zola ${ }^{1}$ ). Thus, the election headquarters, especially those of the Democratic Union for Integration, were demolished, thrown in the air. Free elections in those conditions were a mental fiction and not a reality. But by social theory and practice we know that without free elections there is no free society. If during the electoral process the ballots are stolen, force is applied, intimidation, the vote is taken, then everything in the state goes back: there is corruption, the rule of law does not work, crime grows,there is double morality, no social justice ... Identification of moral boundaries of ethical principles can be decided based on the Aristotelian Golden Mean, the categorical imperative of Kant, the Mill's utilitarianism, the rage of the ignorance of Rawls etc.

In spite of the roughening of sentences and also international monitoring, it can still be seen that there is a spirit of revanchism in our circle and that politics makes people enemies with each other. This was especially present during the 2016 parliamentary elections and local elections of 2017, now between Macedonian parties VMRO and SDSM.

Working against others, after all this, it seems it is becoming the political philosophy and post-electoral strategy of leading parties and opposition parties, doing business as well as other businesses.

In theory, these things tends to explain the sociologist Ervin Gofman, who sees the social world as a natural theater similar to dramaturgy appearances on stage. So, life is in a way a theater in which we try to control the reality that other people see, which he names it as "management of impressions"2.

\footnotetext{
1. Available: https://www.google.com/search?q=zola+rucni+bacac+, (23.04.2019)

2. https://www.manage.com/description_goffman_impression_management.html, 2018-06-04
} 
Life is a theater, because in that social interaction there is a front and back region. In the front region there are oligarchic, small in number, but with great power, in the back region is the people, which is in large numbers. Earlier in history for the people there were different names - slave, demos, half-slave, worker, raja. Today, they are the citizens of a state.

Almost in the same situation, in order to define the relation to the other, Jean-Paul Sartre in the 50s of the last century, will build philosophical views on the existentialism of the individual in relation to other social beings. Man pour soi that exists for himself is characterized by self-cross-knowledge

For Sartre, the "in itself" (en-soi) refers to things in the world that simply "are". They are inert, passive, and are not open to change. They can be identified, defined, and objectified. They have an "essence," as Sartre puts it. The "for-itself" (pour-soi), on the other hand, refers to consciousness. According to Sartre, consciousness is "nothing-ness" because it cannot be defined and it does not settle into a stable identity. The for-itself is always changing, always becoming something else by the choices that it makes."1 We must, in our cross-knowledge, have an internal division that often makes us not sincere because our actions are acting. We know people according to the feelings they create in ourselves. Being aware of the other, in a sick way, we notice that we are just tools for them and we fight for a better, more honest treatment. (Sartre, 1985, p. 20-33)².

Francis Fukuyama describes this war - the fight against 'others ideas-in this way; "Experience tells us that if people can no longer fight for a just cause after that issue is resolved, then they will fight against that cause. They will fight against themselves. Lastly, they will fight because life becomes boring; because they can not understand life without war. If the whole world is in peace and democracy then they will fight against that peace and democracy. " 3

The Turkish Padishahs, but others as well, as Orhan Pamuk writes in his book, "I am red," the first thing they did after the defeat of his rival in the field of war is that they have rushed to make books, paintings where he appears as victorious and the other as defeated. But in addition, the Turkish pashas also visited the harems of the adversary and there sought personal fulfillment of victory (Pamuk, 0.2007, 123).

Work against the other - in Macedonia, Kosovo and Albania is even paid by the state.

Today, in our political and social level, we all work against one another. To work against others, strategies must be prepared to carry out self-proclaiming to the people, how to deface the opponent, how to elaborate, reveal discoveries about the shortcomings and weaknesses of the enemy camp. It is summed up in the intentions - to have information that the other is corrupt, unable, to attack for mistakes. The idea is to make as hard as possible their stay in power and their rule. They, again, turn on exasperating, stealing the lives of others while they rule. This logic represents the social practice of all liberal democracies in the world and it is normal that the government is controlled in this way and the opposition-position power is balanced. But the problem of Balkan societies lies in the fact that there is violence in the society, and the overall strategy of relations and the vis-a-vis philosophy with the other are retaliatory. In this case, the papers are constantly mixed in the election process and again we come to the same situation. During these hostilities, the citizens are undergoing their future.

In fighting with the opponent, are recruited samethinkers and allies, as well. In our conditions every rase in power is followed by revenge on the other as soon as possible and as best as four years where the current leaders have been in a lower position. In the end, for all the mistakes of the government - and for non-aggravating court decisions, and for returnees after work-leaving decisions, for unlawful dismissals, and for litigation, and for the demolition of residential buildings All governments have jars with GOLD, and they are either rebalance of the budget, funds from a fund for agriculture, other reserves and discrete funds.

Money secured for covering half of the debts of each municipality. ${ }^{4}$ Thus, we come in a situation that the Government from the budget covers half of the losses of the municipalities and they with these money buy the 114000 euros cars.. The municipality of Struga was renewed by four new cars. If there is not, again, the government's account is locked until money

\footnotetext{
1 Sartre,J.,Paul (2011). -my.blogspot.mk,

2 Sartre J.,Paul ( 1985, Situatat, (pp.20-33).Prishtine: Rilndja

${ }^{3}$ Fukuyama,F.,( 1995) (1995, pp. 18), Фукујама, Френсис. - Крајот на историјата и последниот човек. Скопје: Култура,.

6. (Pamuk, O., ( Un jam e kuqja)2007, 123).Tirane, Scanderbegbooks, ${ }^{3}$

${ }_{4}^{4}$ Башуровски,С., https://tera.mk/обезбедени-пари-за-покривање-на-полов,
} 
is found. No one of those responsible gives an account of it. This is the epilogue of the tragedy. Can there be any common understanding and definition of the situation? Of course, it will be difficult because according to the retaliatory strategy logic, in the upcoming local elections after two years, the disadvantaged and people who now work on contracts from the current opposition parties will be organized under the patronage of their party and not only they will want to return to their workplaces, but the ball will throw it far away - they will look for better seats and besides it will want revenge for their offense at the time of ruling the ruling party. They will also seek compensation for suffering.

From here, whether the people liked it or not,they must rely on parties for many reasons. One of the reasons is that without party engagement most people feel lonely and unprotected. Quarrels, work, party activities also have their own horror and theatrical content; any cell phone, any penny, lunch, hope for work and function, protection for participation in the police and criminality. Elections are also a kind of entertainment in itself; music, free roaming, media, raphael from "kalashnikov". They are a kind of gladiator war. In slavery systems dominate the methods of physical violence. In the systems and conditions of liberal democracy, the main tools are psychological manipulation.

If we can agree that this is our bitter reality, then we must agree that the other governing structure, we liked it or not, will use the same measures when it comes back to power and we will always have party states, ministers parties, mayors ... What's worse, so is formed and kept the party public administration with judges, inspectors, doctors, teachers, policemen whose career depends on the elections.

Can we have after the elections only, say, 500 shifts, as inalienable party assumptions for the realization of electoral programs of the parties that make up the parliamentary majority? If the Obama administration, after taking the power from the KBush to replace only 5,000-6,000 inalienable officers, then it is normal for us to implement the reforms with 500 new people as well. Or Trump's Administration now. I think that only then will we have fair elections and take power without rioting. Only under such conditions governments will be able to deal with economic problems and reforms.

But, unfortunately, these games resembled Sokrati's conversations when the interlocutor does not exist. And whoever comes to position prefers this approach, plays his game against the opponent, the opposition. But our approach would be defective if we did not call the great Rene Dekart for help. In fact, Descartes was forced to search for tragic situations at the end of the 17th century. Wars and religious non-tolerances destroyed, tired and impoverished Europe. This was the unstable political situation and the struggle until the disappearance of Catholics and Protestants in the name of religious dogma. In the midst of that savage war, Descartes begins his pursuit of a new opportunity which must be the philosophy of action of all people and of all religions. And this brought him to his familiar Cogito, based on his philosophy, says llia Prigozhanin.

On the other hand, with regard to Cogito ergo sum, Nigel asks a question on how to keep the world out from the unexpected consequences of human action? This is the philosophical and human obligation of keeping control. But the world is far too easy to become anarchic, out of control. The issue of creating a conscious human society is indispensable for us to care for the world: to have it in control of our products, to shield it from social forces. This will enable us to treat each other as human beings as we are, to treat others as treating ourselves. ${ }^{1}$ (Nigel W. and Others, 2000, 7-15).

\section{METHODOLOGY}

This research aims, through research methods and techniques, using various sources, to gather research data on a very important issue for the Power struggle and the relationship to the other in politics.

For this subject there is a large number of print and electronic media data that researchers make closer to the appearance and concretization of different situations with those we encounter during various election processes, negotiations, debates in the media and parliament etc. . Therefore, in order to deepen the reports of the other in various situations of political struggle, we will use different methods and techniques for gathering the factographic material.

Research analysis

DIFFERENT OPINIONS ABOUT THE STRUGGLE FOR POWER

1. Nigel, W. and Others, (2000, 7-15).Reading Political Philosophy: Open University, London, 2000 
All people know the opposition because it is noisy; it is persistent; it often uses regular forms of struggles for power, such as negotiations, beliefs, media conferences, press releases, and so on. But even more often, it uses irregular forms of riots, protests, petitions, urban disobedience and sometimes in Western Balkan countries, as well as violence. "The Opposition's main role is to question the government of the day and hold them accountable to the public. Some such as Dr Don Brash, National Leader Party, says the Opposition represents an alternative government and is responsible for challenging the policies of the government and producing different policies where appropriate. ${ }^{1}$ While Yadav is of the opinion that the opposition has 4 following issue:

1. To criticise the policies, plans, bills and laws which, in accordance with them, are against the common people's welfare. They should highlight the negative points of these.

The opposition should clear out its stand on each and every issue concerned with the people.lt helps in smooth working of the parliament.

https://www.quora.com/what-is-the-role-of-opposition-in-democracy

2. in some political systems, the elected politicians who belong to the largest party that does not form the government:

3. the Leader of the Opposition

4. The Opposition has/have condemned the government's proposed tax increases.

The Other and Alber Camu

In our country, the war to the disappearance between the parties, under our conditions is done in the name of political dogma, the struggle for power. For Einstein, science (mathematics) is a salvation for everyday life's unrest, and Leibnitz sought non-hateful language, ie tolerance for social divisions and conflicts. In his time,religious conflicts were the wildest. Albert Camus, winner of the Nobel Prize for Literature in 1957, was known for his secret, that he knew "to resist the air of time". Jean Daniel, founder of Nouvel Observateur, says in his book On Camus that he was "hermit and solidar". He found it difficult to accept the great blackmailing of the times, the divisions and the great absurdities of the time- the Stalinist model in the east, the western one with the dictates of the American market, the consumer society driven by babyboom. $\mathrm{He}$ also criticized re-socialism but also industrial capitalism and his market. Under these principles he will come into controversy and public controversy with his friend Sartre, who reasoned to some extent, the Algerian violence and the horrors of Gulag. Perhaps the greatest philosophical merit of Camus is precisely the relationship between the truth of the victim and the attacker, that is, the goals and the means. His "air of time" was exactly the Hiroshima dust. Just when everyone cries out that the Second World War ended, in this bomb they discovered the magic key to the end of the bloodshed, Camus observed the philosophy "the purpose justifies the means', therefore, the use of enemy weapons." I want to fight for justiceno to punish some and revenge some, "he wrote. Only clean-minded judges should be trusted, he says. So Camus rose up against revenge because it would otherwise resemble the terror that the revolutionaries of Paris did after the fall of Bastille. They wanted justice to be exercised with vengeance and blood. Daniel's book also speaks of another line-of-line relationship between Cogitos de Dekart and the statement "I doubt, that's why I exist"and Camus's statement "revolt, so we are." He tells the other: "We must love a little, and if possible be happy in our love for others." His statement, "We are of those who can not bear to talk of misery, but knowing the cause" is nothing but "the air of time", whether stalinism, whether the Arab dictatorship or the dictatorship of the market and corporate ...2 (Daniel, J. 2007-70-85)

From what we have said above if we compare it with our air of time we need a broad debate on the moral boundaries of democracy and dialogue as a permanent form of political life. The difference in our case is that there is little tolerance and there is no Cogito at all. The difference is that in these circumstances of the Balkan Path the relationship and the wisdom are relative, the dividing lines between them are lost.

\section{STUDENTS AND THEIR POLITICAL ACTIVITY ${ }^{3}$. RESEARCH}

\footnotetext{
1. Role of the Opposition in the Government. - decisionmaker.co.nz decisionmaker.co.nz/guide2003/hgw/oppose.html Ajay Yadav, 2016

2. Daniel, J.D 2006-70-85) Видови умови, Автор: Даниел К. Денет Издавач: Магор, 2006

3 . Hulumtim në temën "Studentët dhe lëvizjet politike ,"Studimi eshte bere në mostër nga 571 studentë të Universitetit te Shkupit dhe Manstirit, Hasan Jashari and others, 2007.
} 
It is of interest to research student attitudes about political participation, participation in political life, and their role in campaigns, election process. Among us, there are various debates about whether political parties are misusing the students for their purposes or whether the students impose and realize their interests and ideals with their running into political life?

There are constantly problems on the selection of student leaders. They, in our country, are elected with problems, with violation of election procedures up to violence. Membership of students in political parties, as spokespersons, within the youth organizations of political parties, present today the foundations of the political organization, which is also a common scheme of party action in the Republic of Macedonia.

Another dilemma, which is also always current, has to do with the need to accurately learn how much student participation is present in the political life of the state?

Is that enough and are they aware that without their active participation they can not change something in the direction they want - their interests can not be realized. Tockquevile, in his theoretical analysis, sees participation as the basis of democracy.

One of the questions was about active participation in politics

\section{Political engagement}

1. Yes

2. No

3. Sometimes

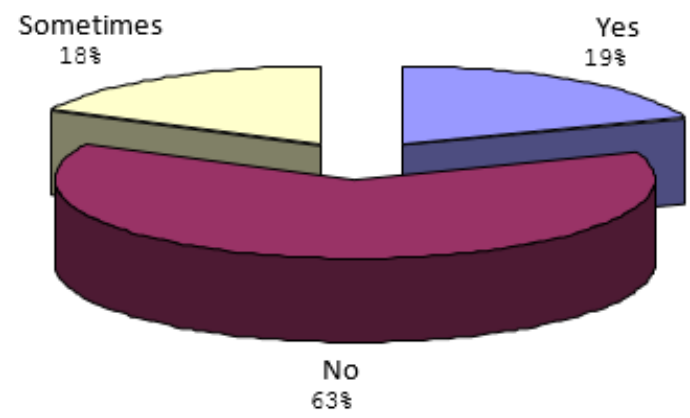

The graph shows membership of students in political parties and that their involvement in politics, by the conversation, is a necessity because in conditions of a still undeveloped democracy, with weak institutions, employment and career advancement are directly related to participation in the campaigns, voting and political activism. But the result shows that only 19 of the respondents are party members.

In questions of like of which event you would travel $5 \mathrm{~km}$ in order to attend, one can conclude that most students love sports events and that 144 of those present say they would walk 5 kilometers.

For religious events, 92 students have been assigned in comparison to 29 that are scheduled for political events.

This seems to be happening in Macedonia and the Western Balkans.

\begin{tabular}{|c|c|c|c|c|c|}
\hline $\begin{array}{l}\text { Having power means having privileges and having a large number of people who } \\
\text { will support, follow. To achieve this, there are regular forms of political warfare and } \\
\text { irregular forms. In politics there are friends and enemies. But the interest is } \\
\text { permanent of the friends and temporary on enemies ... }\end{array}$ & 촗 & 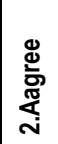 & ம के & 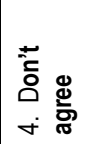 & 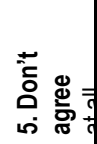 \\
\hline Political parties in Macedonia have a genuine cooperation with each other & 7 & 4 & 17 & 60 & 12 \\
\hline Politicians are loyal to the citizens & 9 & 6 & 27 & 23 & 35 \\
\hline
\end{tabular}




\begin{tabular}{|l|l|l|l|l|l|}
\hline Our political opponent is our friend in politics & 11 & 2 & 20 & 23 & 42 \\
\hline Our political opponent is our enemy in politics & 31 & 18 & 25 & 13 & 13 \\
\hline He who is in power denies rights to the ones that are not part of the government & 29 & 23 & 18 & 13 & 17 \\
\hline Macedonia has discriminatory policies against the other & 37 & 17 & 13 & 23 & 10 \\
\hline $\begin{array}{l}\text { There is political discrimination for those who lose the elections and are not part of } \\
\text { the executive }\end{array}$ & 29 & 9 & 21 & 19 & 22 \\
\hline There is equity in the religious aspect & 10 & 8 & 16 & 23 & 33 \\
\hline In ethnic terms, the concept of equality in everyday life applies & 14 & 11 & 22 & 25 & 28 \\
\hline Do you want your children to live in a society like this you live in? & 7 & 9 & 16 & 31 & 37 \\
\hline
\end{tabular}

Tabela nr. 1. Qwndrimet e studentwve lidhur me perceptimin e tjterit nw politike dhe raporti I Partive politike nw Maqedninw e Veriut vs. tjetrit. Hulumtimi wshtw bwrw me student nw Shkup dhe Tetovw gjatw muajit mars dhe prill 2019. Gjithsejt te anketuar me shkallwn Likert 100 studentw

Nga tabela me lartw shihet se partite poltike ne Maqedoni nuk kanw njw bashkwpunim tw mirwfillt njera me tjetwrn.Kwte e mendojnw $72 \%$ e studentwve. Ata poshtu me njw inetnzitete tw lartw 23 pajtohen dhe $42 \%$ aspak nuk pajtohhen me lojalitentin e partive ndaj qytetarwve. E njejta gjw thuajse paraqitet me pohimin se oponeneti ynw politik wshtw miku jonw ose armiku jonw. Por edhe raportet nw mes Mazhorancws dhe pakicws nw Parlament dhe qeveri janw armiqwsore. Humbwsit- pakica janw tw diskriminuara e mendojnw $52 \%$ e respondentwve, tw cilwt pwrfarwsiht nw tw njejtwn mwnyrw mendojnw edhe pwr poltikat qw praktikohen viza vi tjetrit

Njw numwr relativisht I madh mendon se pwr qwndrimin se There is equity in the religious aspect, nuk pajtohen janw shprehur23, dhe aspsk nuk pajtohen jane $33 \%$. Thuajse e njta gjw pasqyrohet nw pytjen nw numrin 9 pwr konceptin e barazisw nw jetwn e pwrditshme

Dhe sw fundi respondentwt shprehuin mendimin se duhet ndryshime nw moralin shoqwror dhe rendin juridik. Ata nuk pajtohen qw fwmijwt e tyre tw jetojnw nw kwte shoqwri dhe kushte tw jetesws nw tw cilwn jetojnw ata. Vetwm $7 \%$ pajtohen dhe $9 \%$ plotwsisht pajtohen, kurse 16 janw tw pa pwrcaktuar e $31 \%$ nuk duna qw fwmijwt e tyre tw jetojnw kwtu dhe $37 \%$ janw mw tw zwshwm kundwr asaj qw fwmijwt e tyre tw jetojnw kwtu

\section{Conclusion}

In conclusion, I can say that political participation and the voting process in Macedonia still have great development problems. As Old and wise Volter says, they should be cultivated like the garden every day, every week, every season, forever and ever. Because democracy is so, it must be a process that requires active citizen participation today and tomorrow, again and again. And if we are not a participant in the elections and in the political life, we are not bothered by politics, then politics will deal with us.

The political struggle between political opponents is a hacking war that hurt civilians and that war is without moral limits.

Corruption is not fought and some political sets have been in power for 17 years in a row as part of the parliamentary and the government majority.

This thing in the past enabled them plenty of privileges, but also an inexplicable privilege; to set up loyal social control organs against them not to frighten anyone about nepotism, corruption, and ignorance and not doing work. 


\section{References}

[1]. Sartre,J.,Paul (2011). -my.blogspot.mk, available at https://plato.stanford.edu.entries.sartre,23.04.2019

[2]. Sartre J.,Paul ( 1985, Situatat, (pp.20-33).Prishtine: Rilndja

[3]. Fukuyama,F.,( 1995) (1995, pp. 18), Фукујама, Френсис. - Крајот на историјата и последниот човек. Скопје: Култура,. [4].Pamuk, O., ( Un jam e kuqja)2007, 123).Tirane, Scanderbegbooks,

[5]. Башуровски,C., https://tera.mk/обезбедени-пари-за-покривање-на-полов,

[6]. Nigel, W. and Others, (2000, 7-15).Reading Political Philosophy: Open University, London, 2000

[7]. Ajay Yadav Role of the Opposition in the Government. - decisionmaker.co.nz decisionmaker.co.nz/guide2003/hgw/oppose.html

[8]. Daniel, J.D ( 2006-70-85) Видови умови, Автор: Даниел К. Денет Издавач: Магор

[9]. Jashari,H., Hulumtim në temën "Studentët dhe lëvizjet politike ,( 2007)"Studimi eshte bere në mostër nga 571 studentë të Universitetit te Shkupit dhe Manstirit, Hasan Jashari and others..

[10]. Малуф, Амин.- Погубни идентитети (201). Скопје: Матица Македонска, 2001.

[11]. Jashari, Hasan.- Essays in politics and Society, Lulu,(2015), USA

[12]. Jashari, Hasan.- Ese te Filozofisë politike,(2010). Arberia design, Tetovë

[13]. Available at: https://www.google.com/search?q=zola+rucni+bacac+, (23.04.2019)

[14]. Available at https://www.manage.com/description_goffman_impression_management.html, 2018-06-04 